
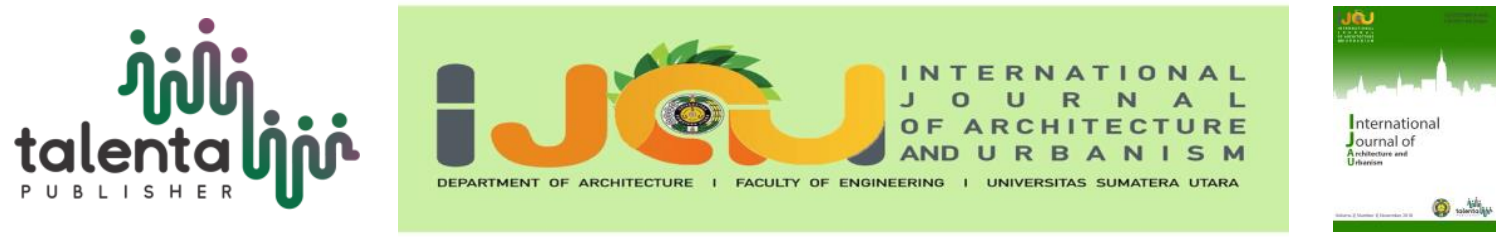

\title{
Medan Plaza Hotel and Mall As One of The Icons of Medan City (Monumental Architecture)
}

\author{
Albert Tambunan ${ }^{I^{*}}$, Wahyu Utami ${ }^{1}$ \\ ${ }^{1}$ Architecture Department, Faculty of Engineering, Universitas Sumatera Utara, Medan, Indonesia
}

\begin{abstract}
Medan Plaza that built in 1982 is one of the pioneers of high-rise malls and buildings that can be considered modern and became the pride of the city of Medan. Over time, more than twenty years later, more and more malls have sprung up in Medan and also building mall coupled with the hotel or apartment. The liability to build high-rise buildings is also the answer to the increasing lack of land in the city center. Besides that, high-rise buildings which interconnected with each other are answers to the needs of the times, that constitute an integrated unit of an organism, the city, which has various activities connected to each other in a system. Hotel and mall have a crucial role in meeting the needs of society. The existence of a single entity with the hotel mall gives ease in meeting the needs of shopping and sightseeing the hotel guests. Facilities at the hotel also required of the general public that with the restaurant, pool, ballroom, gym, etc. Hotel and the mall is a response to the needs of a complex society.
\end{abstract}

Keyword: Hotel, icons, mall, plaza

\section{Introduction}

Hotels always keep up with the times of developing technology and its relationship with business areas around it. The hotel is also a premier part in supporting the world of business and tourism. Nowadays there is a tendency for hotels to be combined with malls in areas that are close to each other, even connected to one another. Therefore, in this case, trying to combine hotels and malls into one unit so that hotel travelers have access to the mall to shop or sightseeing. The mall could be a public space for urban communities. Besides providing a place to shop, the mall can be a gathering place especially the urban youth. About the mall as public facilities can be sawed in the city of Medan is in Sun Plaza and Plaza Medan Fair. According to the times, malls in Medan is also growing and increasingly modern as Plaza Medan Fair (2003), Sun Plaza (2004), Center Point (2013), Lippo Plaza Medan (2016), Manhattan Mall (2017), etc. With the new shopping malls are more modern and attractive, consumer interest towards Medan Plaza and Deli Plaza continues to decrease. However, Medan Plaza is still in demand by grassroots where they can shop and seek entertainment. In

\footnotetext{
*Corresponding author at : Departement of Architecture, faculty of Engineering, Universty of North Sumatra, Jalan Perpustakaan Building J07, Medan 20155, Indonesia

E-mail address: alberttambunan5@gmail.com
} 
contrast to Deli Plaza increasingly dim and eventually closed down because of the many boutiques, restaurants, and kiosks that have been familiar to the city of Medan moved to new malls. However, Deli Plaza has started refurbished to become more modern and has a full function like malls, hotels, offices, and apartments.

\section{Literature review}

Hotel, in general, is a place to stay for people who are on a vacation trip at their destination. According to the project location, this type of hotel is the City Hotel. City Hotel is a hotel located in the center of town and usually accommodate guests who aimed at business or service. Location of the hotel is not always in the city center, but can also spread across parts of the city. Therefore, the intended consumer is a businessman or an official affairs; the chosen location should be close to offices or business area located in the area [1]. A Shopping mall is a stunning place and easy to remember because the building is frequented by residents of the city to shop for daily needs as well as to spend free time. According to the Directorate General of Domestic Trade, Ministry of Commerce of the Republic of Indonesia (1997), a shopping center/trade center (mall/plaza/shopping center), is a sale of various kinds of commodities arena located in the shopping centers. In the shopping center, there are department stores, supermarkets and other shops with a wide range of products [2]. Monumental according to Indonesian dictionary are warning the impression of something great. Monumental architecture occurs because of a difference in the building that makes it different from the surrounding buildings. According to Rasmussen (1964) in his book said that monumental building becomes more effective when it was placed in a row of usage structures, such as Italian churches often were during the Baroque period [3].

\section{Methodology}

The methods in the design stage architecture are divided into two black box method which is the traditional method and the method of a glass box that is a rational method. Methods glass box are selected for use in the design of Medan Plaza Hotel \& Mall as One Icon Medan. The stages and processes of designing are outlined below. This design there are two types of data used, i.e., primary data and secondary data, where the data are obtained through two phases, namely observation and study of literature. Observation is a method of collecting data by direct surveillance of the object to be observed. Study of literature is a method of data collection by taking the data from the documents that there is no direct observation. Data primary is data obtained by observation method to design locations directly. The primary data include location map design, the physical condition of the existing data, and pictures of the results of observations. Secondary data is data obtained directly but without making direct surveillance. Secondary data include existing condition data is data RDTR, comparative study, and study of literature. 
In the site selection method used was first started collecting data to determine the function of the building to be designed and search for relevant data. From the data already obtained building functions the next step is deciding on a suitable location with the functionality. The location determination is done with some consideration that extent, accessibility, achievement, existing purpose, the atmosphere around, and local RDTR. Having selected a site that matches these criteria, the next step is observation directly to obtain the physical data and images of the existing condition. Analysis of experimental data is a logical step after getting the data from the existing physical data collection stage. In this stage, the collected data previously collected, compiled into a narrative form descriptive to be developed in the design stage. Here are some of the stages of the process of data analysis; Analyzes the physical condition of the existing form, analyzing the space requirements and the amount of space, creating design concepts associated with the selected theme, make the appropriate building concept, and make working drawings designed the building.

\section{Results and Discussion}

The average functionality of buildings that surround the project site is commercial buildings. Also, the area is the former site of the famous shopping mall in Medan (Figure 1).

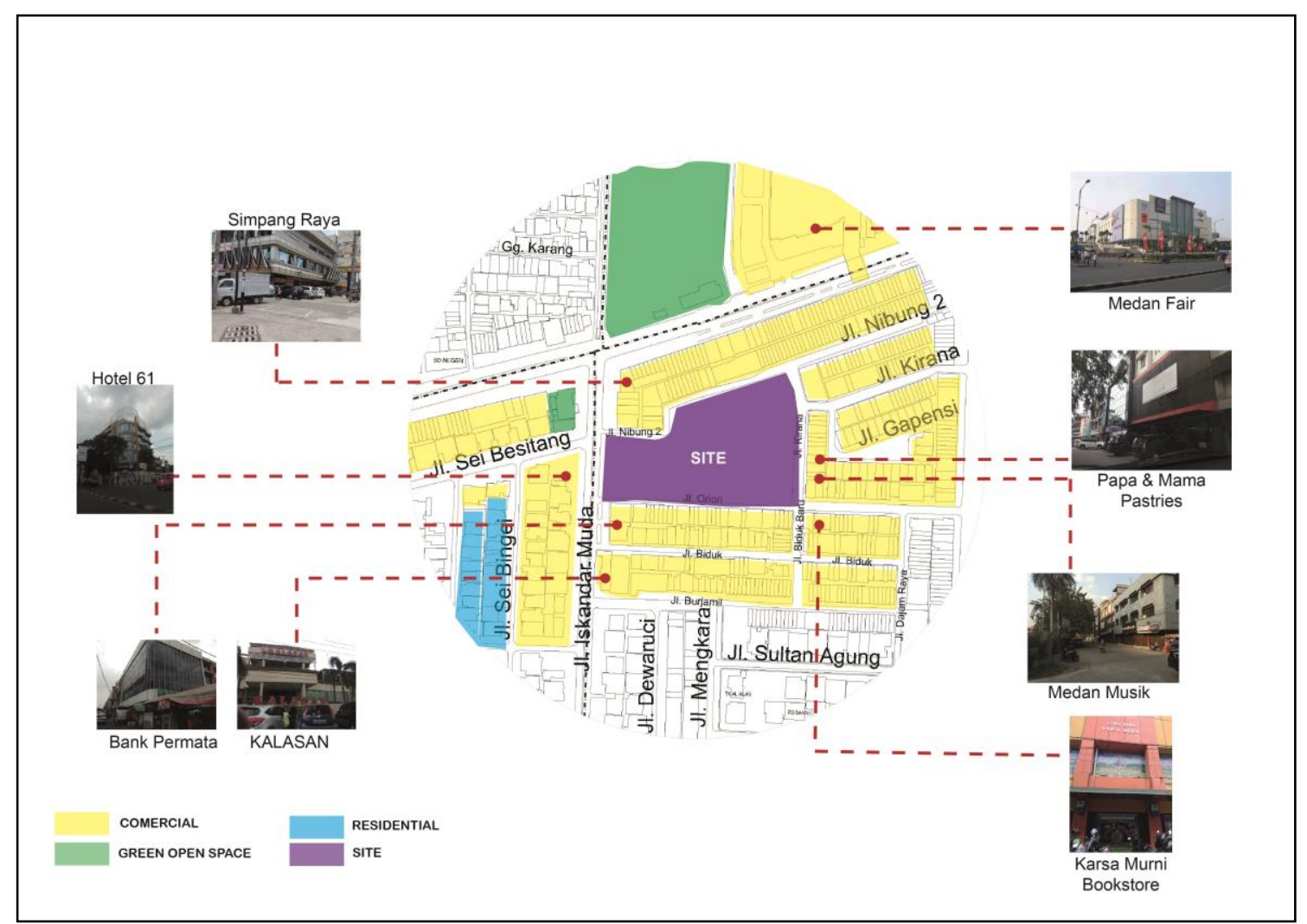

Figure 1. Zoning Analysis 
On any side of the road, we can look at the site will be designed. The position of the building to be the center of attention wherever the positions of visitors are. Although the view obtained average is a shop, which makes the surroundings less attractive and monotonous (Figure 2).

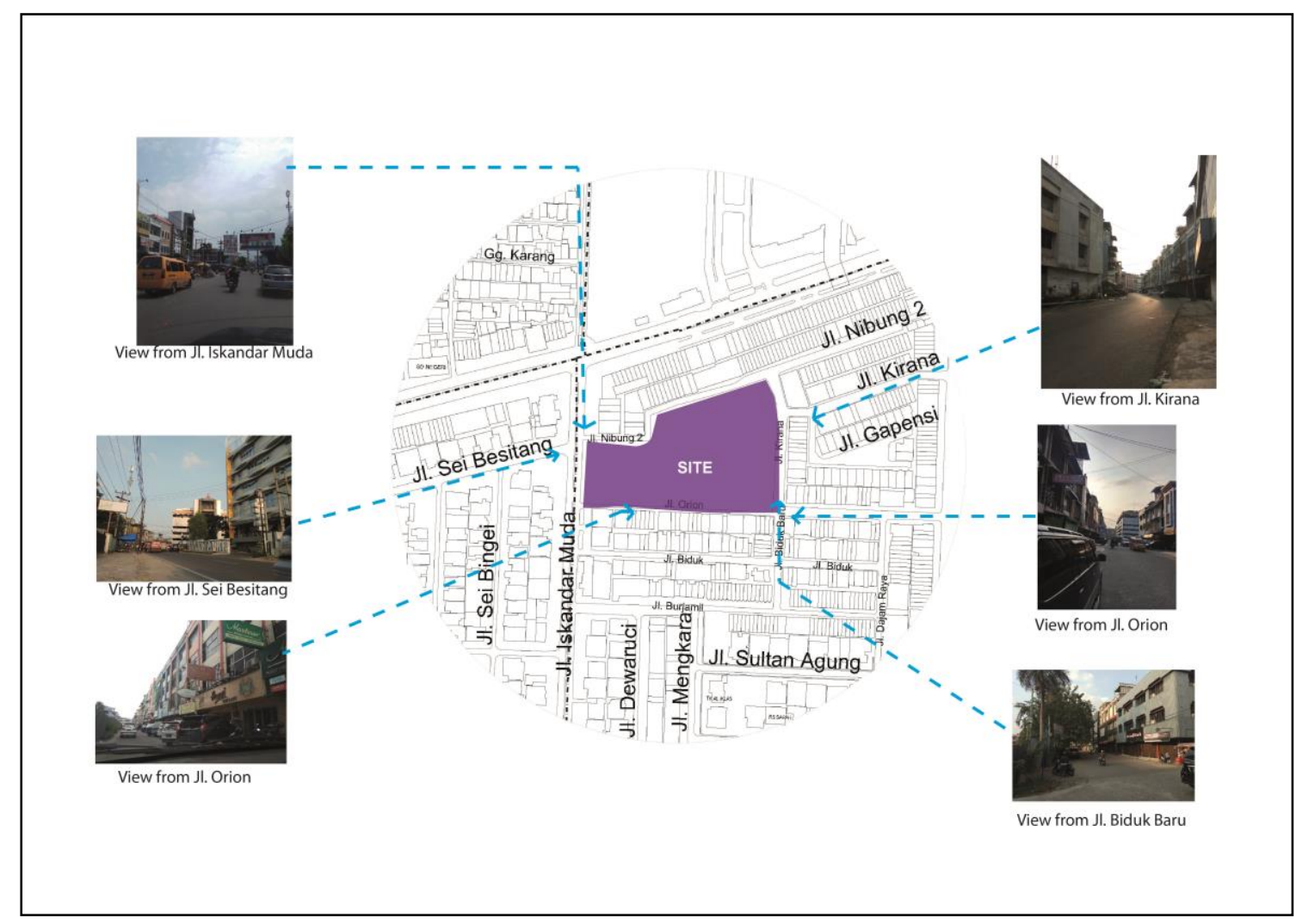

Figure 2. View Analysis

The mass composition begins with a trapezoidal shape and in raising it to form the base of the building. In the next stage, the mass is cut and pushed back, so it has different levels in the building. On the facade of the building ornaments that resemble the shape of a bird, more specifically a phoenix. Where this bird symbolizes immortality or new birth in Greek and Roman mythology. Just like Medan Plaza used to live and have activities and then die, and now born into a new form. At ornaments made such as feathers and mixed color glass shade just like a mixture of dawn sky colors that resembles a phoenix feather. On the facade of the building is a colored sunrise that symbolizes this building be a new start for Medan Plaza.

On the roof, shapes that resemble a bird's wing. Each level of the building has a roof shape is different but with the same concept that resembles the wings of a bird (Figure $3 \& 4$ ). 


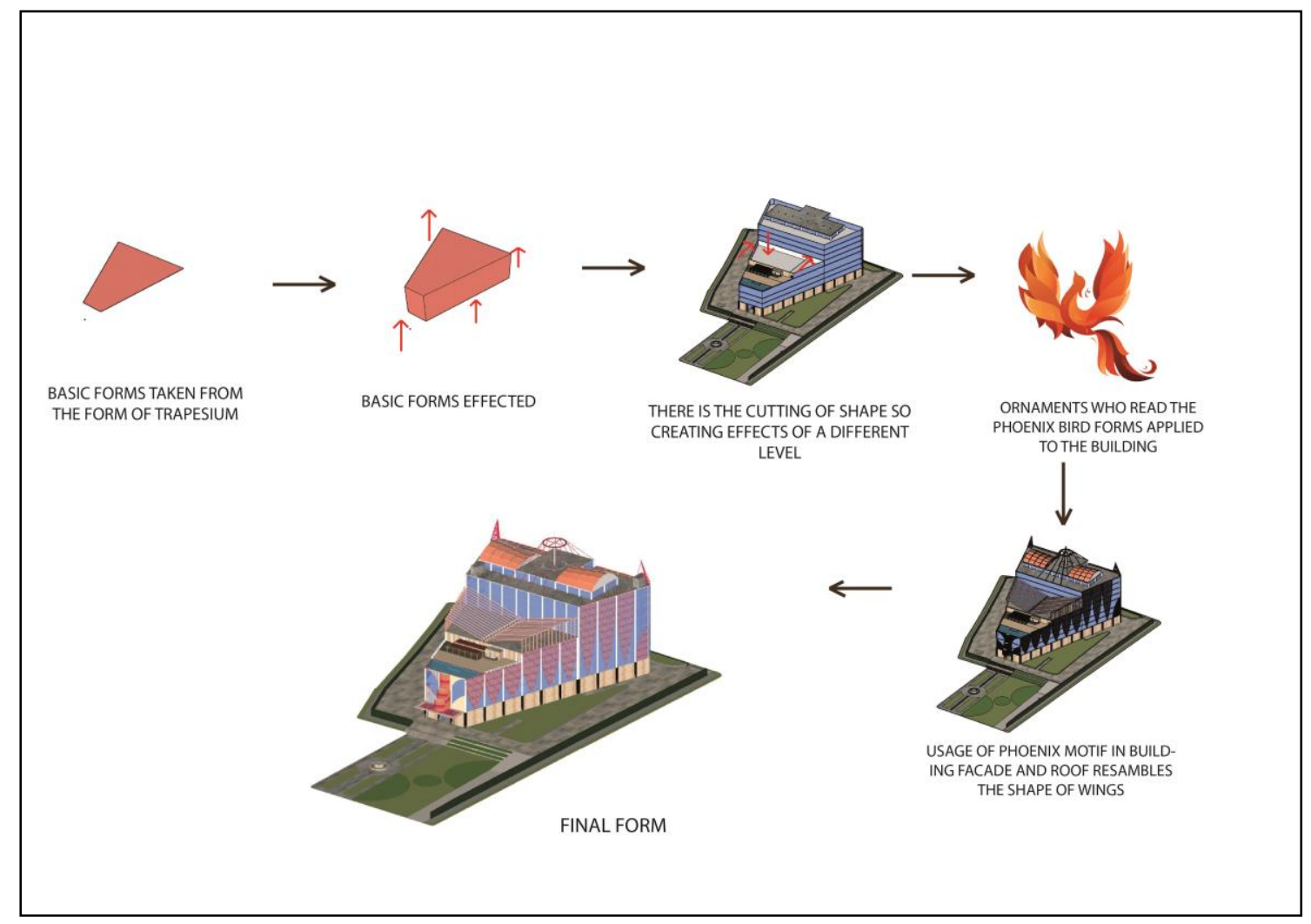

Figure 3. The concept of mass composition

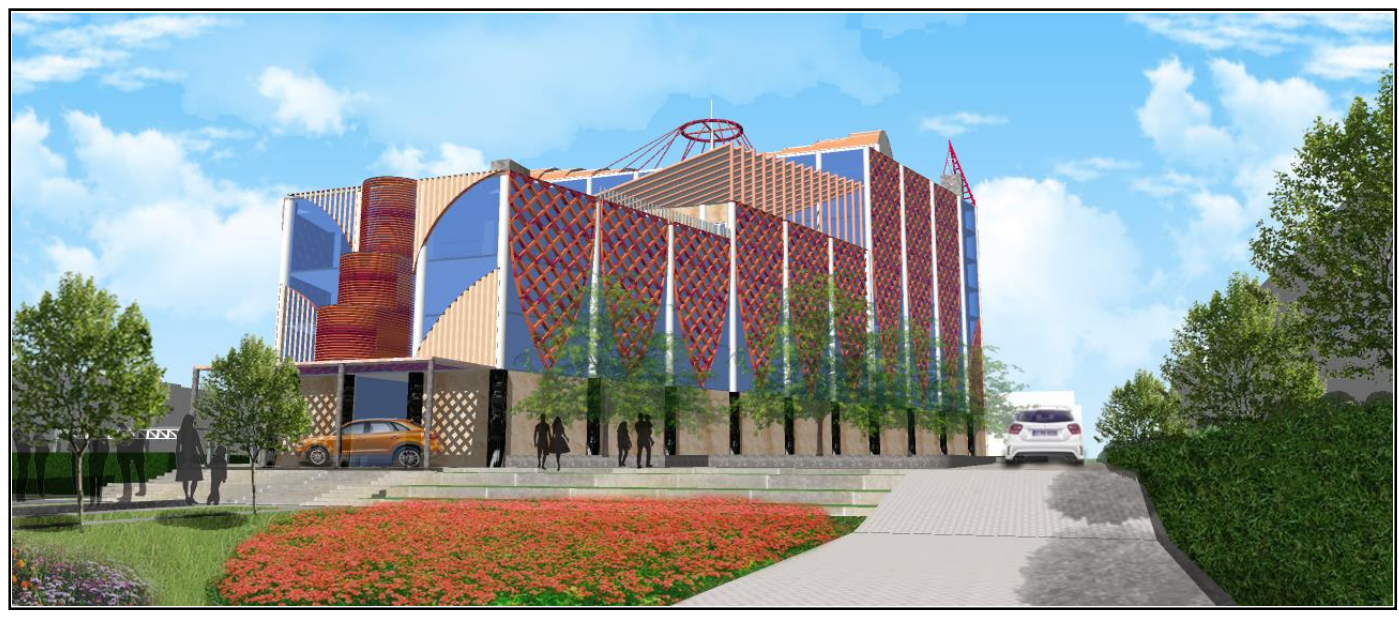

Figure 4. Building Perspective

\section{Conclusion}

Building high-rise buildings in the center of cities are needed because ascetic land is increasingly difficult to reach with sufficient area, so the need to build vertical building become inevitable. Besides high-rise building functions, today tend to be made with a combination of a variety of needs, namely for the hotel and also to the mall, or apartments and malls, and coupled with other functions such as offices, hospitals, universities, and others. By combining multiple purposes in one building activities can save the facility equipment needs of a building, for example, the generator can be used together, powerhouse, chiller, and so on. And the 
management of the hotel and the mall can be incorporated, as well as other employees such as technicians, security, parking attendant.

Medan Plaza, formerly a building that functioned only as a mall, and in the design was made to the mall and hotel. Where limited hermitage land can be utilized as much as possible, for both of these functions to meet current needs. Hotels and malls can be mutually supportive, where hotel guests can take advantage of the mall as a place to meet their needs, especially guests who come as tourists, the mall can provide souvenir items typical local products.

\section{Acknowledgment}

This research is a hotel and mall study carried by two observers. The study results are intended to be recommendations to the Medan City Government for building a new Medan Plaza for solving economic development in the area around the building and make Medan Plaza one of the icons of Medan.

\section{REFERENCES}

[1] Endy Marlina, Panduan Perancangan Bangunan Komersial. Yogyakarta, Indonesia: ANDI, 2008.

[2] Euis Soliha, "Analisis Industri Ritel di Indonesia," Bisnis dan Ekonomi, vol. 15, pp. 130$131,2008$.

[3] Steen Eiler Rasmussen, Experiencing Architecture. Cambridge, England: The Massachusetts Institute of Technology Press, 1964. 